\title{
ASPEK REPRODUKSI IKAN LAYANG DELES (Decapterus macrosoma) DAN SIRO (Amblygaster sirm) SEBAGAI PERTIMBANGAN DALAM PENGELOLAANNYA DI LAUT JAWA
}

\author{
Suherman Banon Atmaja ${ }^{*}$ dan Duto Nugroho*)
}

\begin{abstract}
ABSTRAK
Lebih dari 80\% ikan layang deles (Decapterus macrosoma) dan siro (Amblygaster sirm) di Laut Jawa yang tertangkap oleh pukat cincin adalah ikan-ikan masih belum matang seksual (immature). Hasil tangkapan didominasi ikan berukuran $13-19 \mathrm{~cm}$ (FL). Analisis pengaruh tekanan penangkapan selama satu dekade tidak menunjukkan penurunan ukuran ikan yang tertangkap. Pengamatan terpenting terhadap aspek reproduksi sebagai salah satu dasar bagi pengelolaan sumber daya memberikan informasi bahwa induk ikan dengan kondisi matang telur banyak tertangkap dalam bentuk gerombolan.
\end{abstract}

\section{ABSTRACT: The Reproduction Aspects of Layang Scads (D.macrosoma) and Spotted Sardinella (A.sirm) as a Consideration of Their Management in the Java Sea, by: Suberman Banon Atmaja and Duto Nugrobo.}

More than $80 \%$ of the layang scads and spotted sardine caught by purse seiners biologically were immature fish. The catch was dominated by size of $13-19 \mathrm{~cm}$. Preliminary study on the effect of fishing pressure during the last decade showed that the average size of fish did not significantly decrease. Assessment on the reproduction aspects as a base data for stock management indicate that mature spawners is caught in shoals.

KEYWORDS: Reproduction, Scads, Spotted Sardinella, fisbery management

\section{PENDAHULUAN}

Sebagaimana telah diketahui karakteristik massa air dan iklim Laut Jawa dipengaruhi langsung oleh dua angin muson, yaitu Angin Muson Barat yang berlangsung antara bulan September-Februari dan Angin Muson Timur yang berlangsung antara bulan Maret-Agustus. Pada Muson Timur, massa air bersalinitas tinggi ( $>34$ per mil) memasuki Laut Jawa melalui Selat Makassar dan Laut Flores, sedangkan pada Musim Barat, selain terjadi pengenceran oleh air sungai, juga masuk massa air bersalinitas rendah ( $<32$ per mil) yang berasal dari Laut Cina Selatan mendorong massa air bersalinitas tinggi ke bagian Timur Laut Jawa. Hal ini mempengaruhi temperatur permukaan dan pola arus (Veen, 1953; Wyrtki, 1961).

*) Peneliti pada Balai Penelitian Perikanan Laut, Jakarta 
Pola Angin muson tersebut sangat nyata berpengaruh terhadap kegiatan penangkapan dan keberadaan ikan di Laut Jawa. Pada Angin Muson Timur, ikan yang bersifat stenohaline banyak tertangkap, seperti layang (Decapterus macrosoma dan Decapterus russelli), banyar (Rastrelliger kanagurta) dan siro (Ambligaster sirm). Pada Angin Muson Barat, ikan yang bersifat euryhaline mendominasi hasil tangkapan seperti: kembung (Rastrelliger bracbysoma) dan juwi (Sardinella spp.) (Hardenberg, 1938; Beck dan Sudradjat, 1978; Atmaja dan Ecoutin, 1995; Hariati et al., 1995). Berdasarkan cluster analysis hasil tangkapan pukat cincin, sediaan ikan layang deles (D.macrosoma) dan siro (A.sirm) tergolong ikan bersifat stenohaline, hidup dekat continental shelf edge dan tertangkap pada setiap akhir tahun (Sadhotomo and Potier, 1995).

Tingkat pemanfaatan sediaan masing-masing spesies tersebut berbeda satu dengan lainnya. Coastal dan neritic species misalnya D.russelli, Sardinella spp., bentong (Selar crumenophthalmus) telah dieksploitasi mendekati lebih tangkap, sedangkan oceanic species misalnya D.macrosoma, R.kanagurta, dan A.sirm masih dapat ditingkatkan (Sujastani, 1978; Nurhakim et al., 1995; Sadhotomo dan Potier, 1995). Namun suatu kajian menggunakan model dengan menyertakan parameter populasi dan aspek reproduksi menyimpulkan bahwa tingkat pengusahaan ikan layang deles (D.macrosoma) telah berlebihan dan dikhawatirkan akan mengalami lebih tangkap terhadap induk ikan (Widodo, 1988 dan 1991). Berdasarkan jumlah upaya penangkapan saat ini, sumber daya ikan pelagis kecil telah dieksploitasi oleh berbagai jenis dan ukuran alat tangkap, yaitu sekitar 2440 kapal pukat cincin yang terdiri dari 520 kapal besar, 220 kapal sedang, 1700 kapal mini purse seine dan lebih dari 7000 kapal payang dan gillnet.

Sejalan dengan peningkatan jumlah penduduk maka menjadi konsekuensi untuk menyediakan kebutuhan protein hewani dan lapangan kerja, sehingga di masa mendatang diperkirakan tekanan penangkapan akan terus meningkat. Dalam rangka mengantisipasi perkembangan tersebut, tulisan ini mencoba menghimpun informasi yang berkaitan dengan aspek reproduksi dan munculnya ikan berukuran kecil pada daerah penangkapan.

\section{BAHAN DAN METODE}

Bahan tulisan ini dihimpun dari beberapa laporan terdahulu yang didukung oleh informasi tambahan dari kegiatan penelitian pada daerah perikanan tradisional, antara lain TPI Indramayu (Jawa Barat) pada bulan Februari-April 1995, TPI Sarang (Jawa Tengah), dan PPI Potre (Ujung Pandang) pada bulan Maret-Mei 1995 serta hasil kegiatan penelitian dengan K.M Bawal Putih I di perairan sekitar Pulau Lumu-lumu pada bulan Februari 1995. Pembagian daerah penangkapan mengikuti pola penangkapan perikanan pukat cincin telah dilaporkan oleh Atmaja dan Sadhotomo, 1985 dan Boely et al., 1992 (Figure 1). 


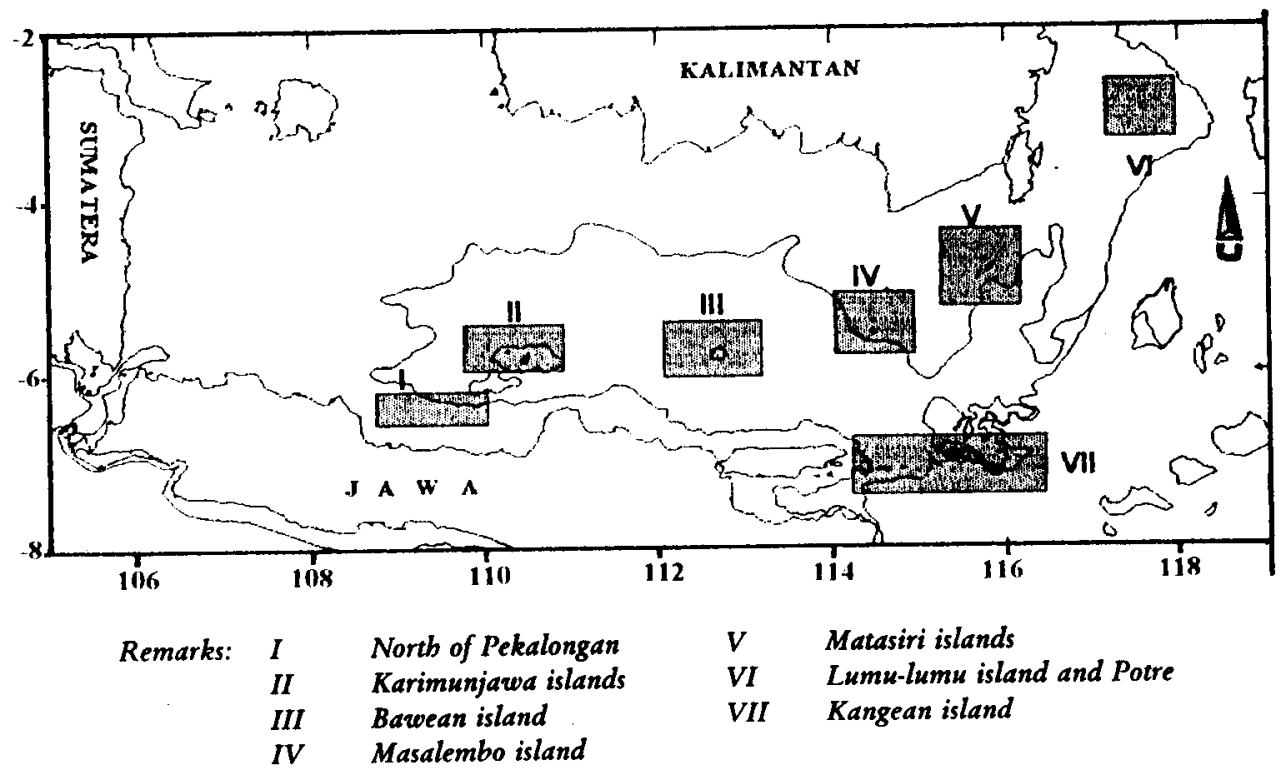

Figure 1. Fishing grounds of purse seine fisbery in the Java sea

Tingkat kematangan gonad ditentukan berdasarkan besarnya ovarium yang menempati rongga perut dan dinyatakan dalam nilai Gonado-Somatic Index (GSI = persentase perbandingan gonad dengan bobot ikan tanpa gonad) dan diameter telur (Atmaja, 1994). Definisi induk ikan dalam tulisan ini adalah ikan dewasa pada kondisi matang telur, telur jernih (translucent egg) di mana besarnya nilai GSI untuk ikan siro sekitar $10-20 \%$ sedangkan ikan layang deles sekitar 10,6-2\%. Perkiraan nilai Lc (ukuran panjang ikan pertama kali tertangkap) diturunkan berdasarkan $50 \%$ frekuensi kumulatif ukuran panjang hasil tangkapan.

\section{HASIL DAN PEMBAHASAN}

\section{Aspek Reproduksi}

Beberapa aspek reproduksi ikan layang deles (D.macrosoma) dan ikan siro (A.sirm) meliputi: ukuran pertama kali matang, fekunditas, musim dan daerah pemijahan telah dilaporkan oleh beberapa peneliti terdahulu. Ikan layang deles mencapai matang seksual pada panjang cagak (FL) $>18 \mathrm{~cm}$, dan ukuran ikan pada saat mencapai matang seksual (Lm) sekitar $20,7 \mathrm{~cm}(\mathrm{FL})$. Ikan berukuran panjang 19,2-20,5 cm (FL) dengan nilai GSI 10,6-22,6 (\%) mempunyai batcb fecundity sekitar 43-88 ribu butir telur. Sedangkan nilai Lm ikan siro sekitar $18,6 \mathrm{~cm}$ (FL), ikan berukuran $17,5-20,5 \mathrm{~cm}$ mempunyai batch fecundity sekitar 15-24 ribu butir telur (Atmaja et al., 1995). Sedangkan hasil penelitian Widodo 
(1991) diperoleh nilai $\mathrm{Lm}$ ikan ini sekitar $15,5 \mathrm{~cm}$ dengan nilai GSI terbesar sekitar $6 \%$. Musim pemijahan ikan siro terjadi pada bulan Februari-Juni, sedangkan ikan layang deles terjadi pada bulan Mei-Juni (Atmaja, dkk, 1995). Selama penelitian periode tahun 1992-1993 induk ikan ditemukan di perairan sekitar Pulau Masalembo dan Pulau Samber Geleng (Table 1). Sedangkan ikan siro ditemukan di sekitar perairan Pulau Masalembo, Matasiri dan Pulau Lumu-lumu (Table 2). Hal ini memberikan suatu indikasi konsentrasi kedua daerah pemijahan ikan ini di sekitar perairan bagian Timur Laut Jawa dan Selat Makassar.

Table 1. Percentage of D.macrosoma (female) at eacb maturity stage by fishing ground

\begin{tabular}{cccccc}
\hline Fisbing & \multicolumn{5}{c}{ Maturity stages } \\
\cline { 2 - 6 } ground & $\boldsymbol{I}, \boldsymbol{U}, \boldsymbol{I I I}$ & $\boldsymbol{I V}$ & $\boldsymbol{V}$ & $\boldsymbol{V I}$ & $\boldsymbol{V I}$ \\
\hline 1 & 100.0 & - & - & - & 20 \\
2 & 99.4 & 0.8 & - & - & 154 \\
3 & 96.9 & 1.1 & - & - & 96 \\
4 & 93.8 & 3.4 & 1.4 & 2.1 & 208 \\
5 & 92.5 & 2.6 & 3.7 & 1.4 & 268 \\
6 & 94.8 & 4.3 & 0.5 & 1.1 & 211 \\
7 & 100.0 & - & - & 0.5 & 150 \\
8 & 93.8 & 2.2 & - & 4.0 & 302 \\
\hline
\end{tabular}

Remarks: 1. Indramayu, 2. Karimunjawa islands, 3. Bawean island, 4. Masalembo island, 5. Matasiri \& Samber geleng, 6. Lumu-lumu island, 7. Kangean islands, 8. PPI Potre (South Sulawesi)

Table 2. Percentage of A.sirm (female) at each maturity stage by fishing ground

\begin{tabular}{crrrrr}
\hline Fisbing & \multicolumn{5}{c}{ Maturity stages } \\
\cline { 2 - 6 } & $I, I I, I I$ & $I V$ & $V, V I$ & $V I I$ & $N$ \\
\hline 1 & \multicolumn{6}{c}{ no data } \\
2 & 100.0 & - & - & - & 120 \\
3 & 97.7 & 2.3 & - & 4.3 & 196 \\
4 & 80.1 & 12.4 & 2.9 & 4.5 & 269 \\
5 & 89.3 & 6.9 & 3.1 & 0.8 & 202 \\
6 & 61.2 & 22.6 & 13.7 & 2.4 & 262 \\
7 & 96.6 & 3.4 & - & - & 342 \\
8 & \multicolumn{5}{c}{ no data }
\end{tabular}

Remarks:

1. Indramayu, 2. Karimunjawa islands, 3. Bawean island, 4. Masalembo island, 5. Matasiri \& Samber geleng, 6. Lumu-lumu island, 7. Kangean islands, 8. PPI Potre (Soutb Sulawesi) 
Keberadaan ikan-ikan ukuran kecil berkaitan dengan pola penyebaran telur dan larva secara pasif terbawa oleh pasang dan arus dari daerah pemijahan ke daerah asuhan (nursery ground). Hasil kegiatan penelitian di atas kapal pukat cincin selama kegiatan survei akustik periode tahun 1992-1995, dan pengamatan hasil tangkapan bagan di sekitar perairan Kepulauan Karimunjawa dan Pulau Bawean tertera pada Table 3.

Table 3. The occurence of small fish caught by fishing ground and gears

\begin{tabular}{cclll}
\hline Species & $\begin{array}{c}\text { Length } \\
(\mathrm{cm})\end{array}$ & Fisbing grounds & Fisbing gears & Periods \\
\hline A.sirm & $4.0-5.5$ & Karimunjawa & Bagan & June, 1992 \\
& $8-11$ & Lumu-lumu & Purse seine & February, 1995 \\
& $5-7$ & Bawean & Bagan & September, 1994 \\
D.macrosoma & $7-9$ & Lumu-lumu & Purse seine & February, 1995 \\
\hline
\end{tabular}

Pengukuran di atas kapal pukat cincin selama mengikuti survei akustik menunjukkan bahwa, kedua jenis ikan berukuran kecil tersebut ditemukan di perairan Pulau Lumu-lumu pada bulan Februari 1995, dan hanya terdapat pada 1 kapal dari pengambilan contoh pada 6 kapal yang beroperasi di perairan tersebut. Hal ini mencerminkan bahwa ikan-ikan ukuran kecil bukan merupakan sasaran utama (target species) penangkapan. Ikan berukuran kecil tertangkap oleh perikanan pukat cincin secara kebetulan bersama ikan berukuran besar (Figure 2), sedangkan munculnya ikan kecil di perikanan bagan bersamaan dengan musim ikan teri (Stolephorus spp.) yang terjadi pada bulan April-Agustus. Di perairan sekitar Kepulauan Karimunjawa dan Pulau Bawean, ikan-ikan ukuran kecil hanya sekitar $10-15 \%$, terutama ikan siro dan banyar. Willoughby et al. (1984) melaporkan bahwa hasil tangkapan bagan di pantai Utara Jepara, sekitar $9 \%$ dari berat hasil tangkapan adalah S.gibbosa dan D.acuta.

Dengan demikian ikan pelagis ukuran kecil tidak tertangkap bersamaan, hanya ikan siro memasuki daerah penangkapan pukat cincin dan bagan, sedangkan ikan layang deles relatif tidak masuk daerah penangkapan. Hal ini diduga berkaitan dengan perbedaan mekanisme pola penyebaran telur dan larva, dan proses pemijahan, serta respon masing-masing ikan terhadap kondisi lingkungan yang cocok.

Bagaimanapun nelayan akan menghindari ikan kecil berukuran di bawah ukuran $9 \mathrm{~cm}$, selain tertangkap secara terjerat ( $\mathrm{gilled}$ ) yang menyebabkan ikan cepat rusak, juga ikan bernilai ekonomis rendah. 


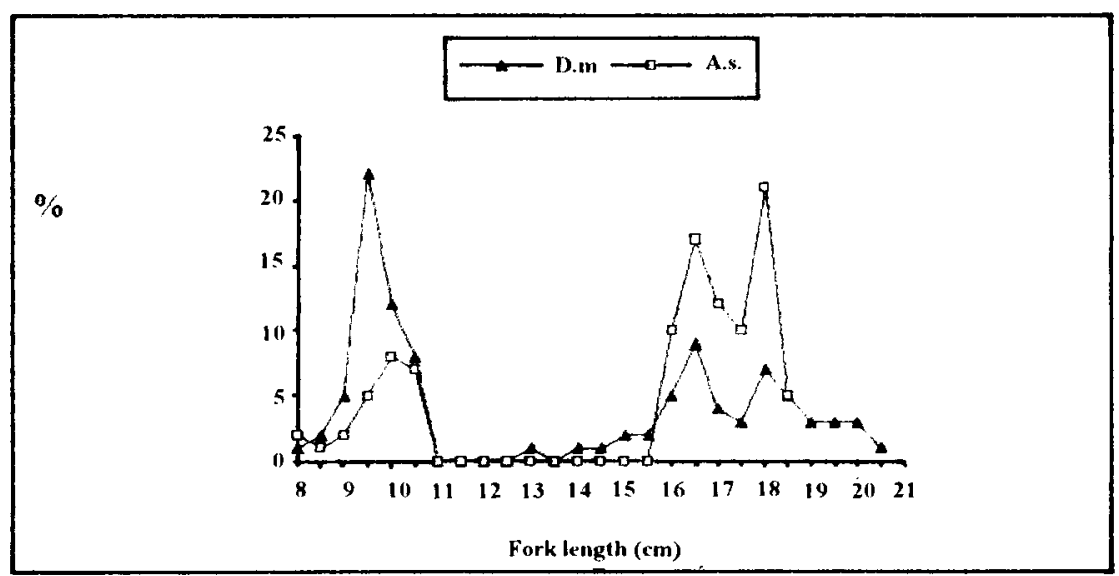

Figure 2. Length frequency of $A$. sirm (As) and D. macrosoma (Dm) around Lumu-lumu waters

\section{Hubungan Nilai Im dan Le}

Pada Table 1 dan Table 2 tampak ikan siro belum matang seksual mencapai $87 \%$ dan ikan layang deles mencapai $96 \%$. Persentase frekuensi kumulatif hasil tangkapan menurut ukuran ikan (Figure 3) dibandingkan dengan nilai Lm memperjelas bahwa lebih dari $80 \%$ hasil tangkapan ikan layang deles dan siro di bawah nilai Lm. Handerberg (1938) menyimpulkan bahwa ikan layang bermigrasi ke Laut Jawa ketika ikan ini masih belum dewasa, sedangkan De Jong (1940) melaporkan sulit menemukan ikan pada kondisi matang telur di perairan Laut Jawa kendati pada puncak musim pemijahan (April-Mei).

Pada Figure 3 dapat dilihat bahwa nilai Lc ikan layang deles (50\% frekuensi kumulatif hasil tangkapan) pada tahun 1985 (FL $=15,1 \mathrm{~cm}$ ) (Atmaja, 1988) dan tahun $1992(\mathrm{FL}=15,3 \mathrm{~cm})$ relatif sama, sedangkan nilai Lc ikan siro pada tahun 1992 sekitar $17,0 \mathrm{~cm}$, hasil sampling tahun 1983 menujukkan nilai $\mathrm{Lc} 18,8 \mathrm{~cm}$ (TL) (Dwiponggo et al., 1986) atau $\mathrm{FL}=16,65 \mathrm{~cm}$ diperoleh dari persamaan $\mathrm{TL}=-0,2774+1,1462$ FL. Dengan demikian nilai Lc selama hampir satu dekade hampir relatif sama dan tekanan penangkapan tidak menyebabkan menurunnya ukuran ikan yang tertangkap. Berarti ikan berukuran $13-19 \mathrm{~cm}$ mendominasi hasil tangkapan atau ada kecenderungan nelayan menuju suatu daerah penangkapan di mana terdapat ikan ukuran besar. 


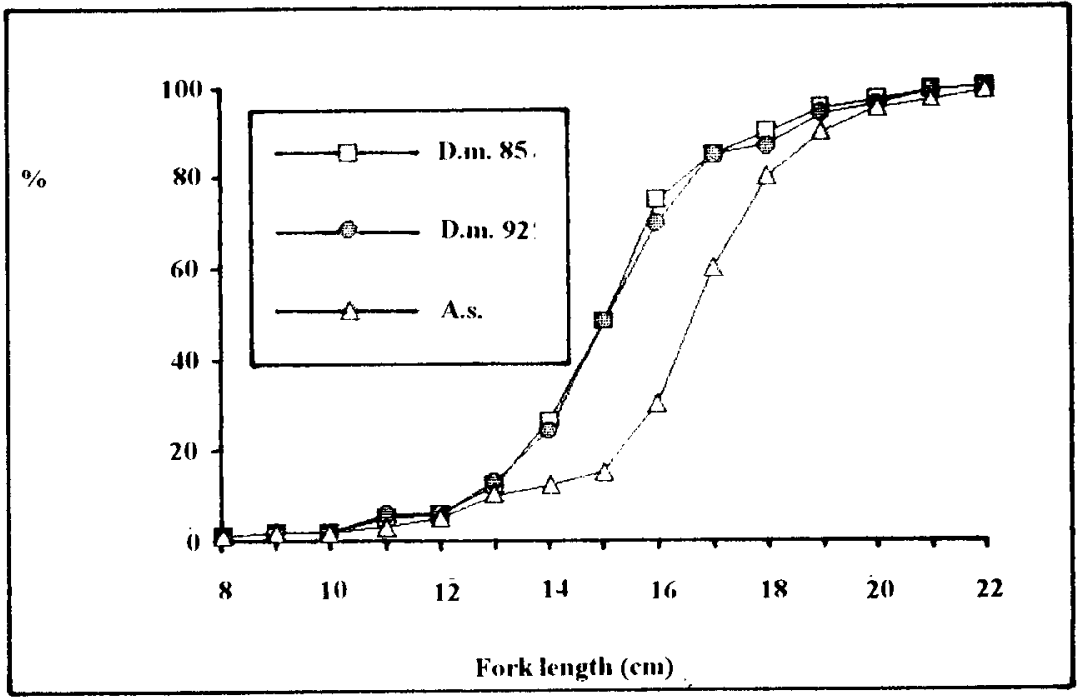

Figure 3. Cumulative frequency of A.sirm (As) and D.macrosoma (Dm)

Figure 3, Table 1 dan Table 2 tidak menerangkan bentuk tertangkapnya induk ikan (ikan dewasa pada kondisi matang telur), apakah bersifat gerombolan atau kebetulan. Kenyataan di lapangan, kedua induk ikan jenis tersebut tertangkap oleh pukat cincin sangat berbeda. Induk ikan siro tertangkap secara gerombolan, terutama pada tahun 1993, sedangkan spesimen induk ikan layang deles sulit ditemukan.

Munculnya induk ikan siro di daerah penangkapan belum dapat dipastikan, apakah berkaitan dengan perjalanan ke daerah pemijahan atau telah terjadi penyimpangan kondisi lingkungan, pada tahun 1993 ditandai terjadi banjir di beberapa kota di Jawa. Aktivitas reproduksi ikan akan menyesuaikan terhadap tersedianya makanan yang optimal bagi pertumbuhan larva dan ikan kecil (Cushing, 1990). Pada kondisi yang tidak menguntungkan kemungkinan ikan tidak mencapai matang atau lambat matang seksual (atresia), sehingga akan menyebabkan kegagalan atau lambat pemijahan. Kelimpahan juwana S.longiceps berkorelasi positif dengan curah hujan pada musim pemijahan dan berhubungan antara jumlah ikan dewasa pada kondisi atresia dengan curah hujan (Raja, 1973 in Longhurst and Pauly, 1987).

Penelitian perikanan sering tidak mengamati secara rinci mengenai induk ikan (ikan siap memijah). Ini dibuktikan dari beberapa penelitian, misalnya Sardinella sirm di perairan Tuticorin (India), yang pada penelitian sebelumnya dikatakan bahwa ikan ini diduga memijah di perairan laut dalam, karena tidak ditemukan ikan dewasa pada kondisi matang telur, pada penelitaan berikutnya 
dilaporkan bahwa ikan telah mencapai matang telur bermigrasi ke arah daerah pantai (Lazarus, 1990). Ronquillo (1974) dalam Longhurst dan Pauly (1987) menyatakan bahwa perikanan di perairan Philipina didukung oleh ikan layang (D. russelli dan $D$. macrosoma) kelompok ikan muda di bawah $20 \mathrm{~cm}$.

\section{KESIMPULAN}

Dari uraian di atas dapat diambil kesimpulan sebagai berikut:

1. Induk ikan siro mudah tertangkap ketika bergerombol untuk memijah, sedangkan ikan layang deles relatif sulit diperoleh dari hasil tangkapan pukat cincin.

2. Dari pengamatan eksploitasi ikan layang deles dan siro selama satu dekade relatif tidak terjadi perubahan rata-rata ukuran ikan yang tertangkap.

3. Ikan siro dan layang deles dari hasil tangkapan pukat cincin didominasi oleh kelompok ikan muda dan reproduksinya tidak aktif.

\section{SARAN}

Sampai sejauh ini, penelitian belum dapat menjawab dampak tertangkapnya gerombolan induk ikan siro terhadap rekruitmen, begitu juga hubungan tekanan penangkapan kelompok ikan muda layang deles terhadap penurunan induk, sehubungan kurangnya informasi keberadaan ikan-ikan berukuran kecil yang tertangkap oleh perikanan tradisional.

Sebagai bagian dari perencanaan pengelolaan sumber daya perikanan pelagis di perairan Laut Jawa, seyogyanya penelitian di masa akan datang dapat lebih ditekankan pada upaya mencari informasi yang lebih rinci seperti halnya data hasil tangkapan dan daerah penyebaran gerombolan ikan yang akan memijah yang didukung oleh karakteristik lingkungannya.

Puncak munculnya ikan berukuran kecil, pola fluktuasi komposisi dan ukuran panjang hasil tangkapan pada perikanan tradisional di perairan sekitar pulau-pulau di perairan Laut Jawa, seperti halnya pada perikanan bagan dan payang, dirasakan perlu diteliti secara lebih seksama sebagai masukan dalam proses analisis untuk menjawab permasalahan di atas.

\section{DAFTAR PUSTAKA}

Atmaja, S.B dan Ecoutin, J.M. 1995. Mini purse seine fisheries in North Java coastal waters. Java Sea Pelagic Fisheries Assessment Project Report (memeo)

Atmaja, S.B., B. Sadhotomo dan Suwarso. 1995. Reproduction of main small pelagic species in Java Sea. Workshops biology, Dynamic and Exploitation of small pelagic in Java Sea. Jakarta. 
Atmaja, S.B., 1994. Tingkat Kematangan gonad beberapa ikan pelagis kecil dari Laut Jawa. Jur. Pen. Perik. Laut (92). 1-8.

Atmaja, S.B. 1988. Estimation of growth and mortality of round scad (Decapterus macrosoma) in the Java Sea in contribution to tropical fisheries biology: paper by participant of FAO/Danida Follow-Up Training Courses (Venema, S. J.M Christensen and D. Pauly; Eds.). FAO Fish. Report (389). 324-345.

Atmadja, S.B. dan B. Sadhotomo. 1985. Aspek operasional perikanan purseseine di Laut Jawa. Jur. Penel. Perik. Laut. No. 32: 65-71

Beck, U. and A. Sudradjat. 1978. Variation in size and composition of demersal trawl catches from the North Coast of Java with estimated growth parameters for three important food-fish species. Mar. Fish. Res. Rep. (spec. Rep.) Contrib. Demersal Fish. Proj. Jakarta. 4: 1-80.

Boely, T., M. Potier and B. Sadhotomo. 1992. Evolution and pattern of a fishing system. The large purse seine. Third Asian Fishery Froum.

Cushing, 1990. Plankton production and year-class strength in fish population: an update of the match/mismatch hypothesis in Marine Biology, (Blaxter J.H.S. and A. J. Southward eds.). Academic Press.

Dwiponggo, A; Haryati; Atmaja, S.B; Pelamores, M.L; Pauly D. 1986. Growth, mortality and recruitment of commercially important and penaeid shrimps in Indonesian waters. ICLARM. Tech. Rep. 17. 91 hal

De Jong, J.K. 1940. A preliminary investigation of the spawning habits of the fishes of the Java Sea. Treubia, 17:307-330.

Hardenberg, J.D.F. 1938. Theory of migration of layang (Decapterus spp) in the Java Sea. Med. Inst. Zeevisscherij. Batavia: 124-131.

Hariati, T, Maria M.W, Suwarso, D. Krissunari, 1995. North Java coast fisheries: Preliminary observations on seine-nets exploitation. Workshops Biology, Dynamic and Exploitation of small pelagic in Java Sea. Jakarta.

Lazarus, S. 1990. Studied on the spawning biology of trenched sardine, Sardinella sirm (Walbaum) from Vizhimjam, South-West coast of India. India. J. Fish. 34(4). 335-346.

Longhurst, A.R and D. Pauly. 1987. Ecology of tropical oceans. Academic Press Inc. New York. 407 hal.

Nurhakim, S., B. Sadhotomo and M. Potier. 1995. Composite Model on Small Pelagic Resources in Potier and Nurhakim (Eds.) BIODYNEX. Biology, Dynamics and Exploitation of the small pelagic in Java Sea. ORSTOMAARD. Jakarta. pp.145-153. 
Sadhotomo, B. and M. Potier. 1995. Exploratory scheme for recruitment and migration of main pelagic species in the Java Sea. Workshops Biology, Dynamic and Exploitation of small pelagic in Java Sea. Jakarta.

Sadhotomo, B. 1991. Dampak penangkapan ikan muda terhadap produktivitas perikanan (Simulasi kasus perikanan lemuru, Sardinella longiceps di Selat Bali). Jur. Pen. Per. Laut: No. 60. 51-66.

Sujastani, T. 1978. Perhitungan besarnya stock sumber-sumber perikanan di Laut Jawa berdasarkan data statistik perikanan daerah. Simposium Modernisasi Perikanan Rakyat I, Jakarta.

Widodo, J. 1991. Maturity and spawning of shortfin scad (Decapterus macrosoma)(Carangidae)) of the Java Sea. Asian Fish. Sci. 4: 245-252.

Widodo, J. 1988. Population dynamics and management of "ikan layang", scad mackerel, Decapterus spp. (Pisces Carangidae) in the Java Sea. Ph.D. dissertation School of Fisheries, University of Washington, Seattle. 150 hal.

Willoughby, N.G, Zarochman and Rosyid, A. 1984. Preliminary studies on the "bagan" (lift net) fisheries of Jepara, Central Java, Oseanologi Di Indonesia, LON, LIPI. No. 13-24.

Wyrtki, K. 1961. Physical oceanography of the South-east Asian waters. Naga Report. Scripps. Inst. Oceanogr. Univ., Calif., 2,1-195.

Veen, P.CH. 1953. Preliminary charts of the Indonesian archipelago and adjacent waters. Org. Sci. Res. Indonesia. 17. 46 hal. 